whistle. As the ground was sloping, the walk was to be a curve; and Buhler, with little hesitation, pointed out the places where pegs should be laid by a man who opened a narrow path with a hatchet. Buhler did not retrace his steps, and left my grounds after saying that he had pegged the right side of a walk three metres broad. He then complained of the difficulty he had experienced because that stupid darkie had whistled in place of shouting. When the ground was cleared a few days afterwards, I found the curve even and seemingly faultless. When listening to each whistle Buhler turned his face, not towards it, but in the direction of the curve which must ultimately meet it. Have not English landscape gardeners the same faculty of iudging rightly direction by sound.

Abbadia, Hendaye, December II

\section{Dante and the Southern Cross}

THE question "where Dante could have learned about this constellation" (ante, p. I 52) has been discussed by most modern commentators on the passage referred to. The general conclitsion arrived at seems to be that it was throngh the delineation of the "quattro stelle" on Arabian celestial globes. The best scientific discussion of the question will be found in Humboldt's Kosmos ii. 205, 6 (ed. 1870). Might not, however, the line "Non viste mai fnor ch' alla prima gente"' suggest that Dante's knowledge was derived from some record or tradition, of the visibility of these and other southern stars to the inhabitants of the Mediterranean shores before the precession of the equinoxes carried them below their horizon ? "Prima gente"-generally rendered "our first paren s"--recalls irresistibly Horace's " prisca gens mortalium."

University Hall, December I8

YOUR correspondent who inquires whence Dante obtained his knowledge of the existence of the Southern Cross may be referred to Humboldt's travels for one explanation of this remarkable fact. I apprehend your correspondent alludes to the lines"To the right hand $\mathrm{I}$ turn'd and fix'd my mind On the other pole attentive, where I saw Four stars ne'er seen before save by the ken Of our first parents. Heaven of their rays Seem'd joyous. Oh thou northern site ! bereft Indeed, and widow'd, since of these deprived."

Dr. Barlow, the commentator of Dante, accepts Humboldt's explanation, and says: "The principal stars of this constellation were known when Dante wrote, and in the description here given there is a reality attested by all who have seen them. They were once visible in our northern hemisphere." Alexander von Humboldt, from whose philosophic soul the poetry of nature was never absent, says of them :- "In consequence of the precession of the equinoxes, the starry heavens are continually changing their aspect from every portion of the earth's surface. The early races of mankind beheld in the far north the glorious constellations of the southern hemisphere rise before them, which, after remaining long invisible, will again appear in these latitudes after a lapse of thousands of years. The southern Cross began to be invisible in $53^{\circ} 30^{\prime}$ north latitude, 2900 years before our era, since, according to Galle, this constellation might previously have reached an altitude of more than $10^{\circ}$. When it disappeared from the horizon of the countries of the Baltic the great pyramid of Cheops had already been erected more than 500 years." Barlow therefore infers with Humboldt that Dante knew of the Southern Cross by tradition, and adds that the words our "first parents" do not refer to Adam and Eve, but to the early races which inhabited Europe and Asia. Grosvenor Street SAMUEL WILKS

\section{Helophyton Williamsonis}

I AM sorry to see that I have overlooked two mistakes in my brief note which you puhlished in your last number (p. 124). In the fifth line Hymenophylloides should have been Myriophylloides; and lower down Urrger should of course be Unger.

Victoria University, Manchester, December 9

\section{A Smokeless London}

Ir is not very improbable that we shall in a few years be indebted to the electric light for our source of nightly illumina- tion. Before such an eventuality it would be interesting to know if there are any serious objections to employing hydrogen gas as our heating agent. Smokeless and innocuous in combustion, it would relieve us from many ills under which we labour now. When it was tried-after impregnation with a hydrocarbon-as a lighting agent (at Chichester, I believe) some years ago, it was found wanting, but there was no difficulty, I think, experienced in producing it cheaply from the decomposition of water and in sending it through the mains. No notice, I believe, has been directed to this at the Smoke Abatement Exhibition. Will you lindly raise the issue, and let us know the advantage or disadvantage of the project?

I, Onslow Place, S. W., December I6

\section{Meteors}

ON the evening of Wedue day, November I6, whilst sweeping the western heavens in search of comets, I was startled by a brilliant illumination to my right. Looking up hastily, a bright meteor was seen moving rapidly in the north-eastern heavens; it started about $3^{\circ}$ north of Capella, and traversed a path of $s$ me $\mathrm{IC}^{\circ}$ in a north-easterly direction, passing about $2^{\circ}$ above (or west of) $\delta$ Auriga. Its flight did not exceed three seconds, when it bur-t with a dazzling brilliancy to be compared only to the whiteness of the electric light. At the moment of bursting, it must have been at least five or six times as bright as Venus at her maximum. It left in its wake, covering the full length of its path, a thin, reddish train, which drifted slowly toward the north-east among the stars, gradually collecting into a lightish cloud at its north-east end. Noting the remarkable permanency of the train, I turned the telescope (a 5 inch refractor) upon it, and was surprised to see a brightly-glowing mass of pirkish smoke. The same matter was stretched out toward the southeast into a long, straggling strip. This trail was about $1_{4}^{\circ}$ in breadth, and could be plainly seen with the telescope for a distance of at least $10^{\circ}$. The whole of this drifted north-easterly over the stars, curling slowly like a mighty serpent; it was knotted in places with cunsulus forms, probably due to minor explosions in the meteor. The outlines of this wonderful train of celestial smoke were well defined ; it did not diffuse itself into the atmosphere, but gradually faded, becoming more contorted each moment. During the whole time of its visibility it retained its pinkish colour. The first appearance of the meteor was at $6 \mathrm{~b}, 48 \mathrm{~m}$. local time; the train remained visible to the noked eye for about six minutes. In the telescope it was distinct up 'o seven o'clock, and at $7 \mathrm{~h}$. $03 \mathrm{~m}$. it could still be seen in the instrument. While visible, it drifted about $4^{\circ}$ to the north-east. No explosion was heard, though listened for. Latitude of place of observation, $36^{\circ} 10^{\prime}$ north; longitude west of Greenwich, $86^{\circ} 49^{\prime}$.

Nashville, Tennessee, U.S.A., November 27

E. E. BARNARD

ON Wednesday, December 14, at 10.30 p.m., I saw a very brilliant meteor. It appeared to start froin the barren region of the Lynx, bordering on the Twins, a little to the east, and above Pollux, and travelled in the direction of Canis Minor. It was much brighter than any object then shining, though Jupiter and Sirius were both visible, and left a train of light behind which appeared to be granular, of a dull red colour, and fusiform in shape. I did not see the meteor through its entire path, on account of a houve intervening, but the train of light behind it was not visible at the commencement of its path, and appeared to terminate before the disappearance of the meteor. This was by far the brightest meteor I ever saw. The same evening and the week previously I saw many meteors in the region of Aries, but none very brilliant.

Sheffeld Museum and Obsersatory, December I8

\section{Herbaceous Stem on a Palæolithic Implement}

INSTANCES are so extremely rare where vegetable material (as old as the drift gravels) is found adherent to drift implements, that the following instance is probably worthy of note :Amongst my collection of Palæolithic implements from the neigh. bourhood of Bedford, I have one perfectly unabraded example -bright ochreous yellow in colour from its long deposition in the drift. Near the middle of the implement there are the remains of some herbaceous stem firmly fixed to the flint; the colour of the vegetable material is bright ochreous, and under the microscope the vegetable structure (especially the vessels) is most clearly 